\title{
DEVELOPMENT OF X-RAY FLUORESCENCE TECHNIQUE FOR THE URANIUM DETERMINATION IN MONGOLIAN COAL, COAL ASH, AND PHOSPHATE ORE
}

\author{
T.Yu. Cherkashina', D. Bolortuya', A.G. Revenko', P. Zuzaan² \\ ${ }^{1}$ Institute of the Earth's Crust, SB RAS \\ 128 Lermontov St., Irkutsk, 664033, Russian Federation \\ tcherk@crust.irk.ru \\ ${ }^{2}$ Nuclear Research Center, National University of Mongolia \\ University street-1, Ulaanbaatar, 210646, Mongolia
}

Submitted 26 September 2014, received in revised form - 6 November 2014.

The results of the determination of uranium in Mongolian brown coal, coal ash, phosphate rock, and technological samples by X-ray fluorescence (XRF) spectrometry are presented. Technological samples were produced from phosphates by chemical treatment. Powder geological samples and Certified Reference Materials (CRMs) were pressed as tablets. For chosen conditions of the sample preparation procedure analytical figures of merit were carefully studied, as exemplified by the rock and uranium ore Reference Materials. The variance of the total uncertainty is $2 \%$ for uranium in the analyzed samples, and one is $7 \%$ in the rock CRMs. The estimated values of the uranium detection limit for the CRMs are within the interval from 1 to $3 \mathrm{ppm}$. For the correction of the matrix effects the background standard method was used. Values of the uranium contents in the studied samples vary within the interval from 3.0 to $35.0 \mathrm{ppm}$.

The comparison of the wavelength dispersive (WD) XRF results with the energy dispersive (ED) $\mathrm{XRF}$ results and the neutron activation analysis (NAA) was performed. It is demonstrated that the WDXRF have satisfactorily agreed with the EDXRF results and the NAA within the limits of the uncertainty. It is shown that the values of the relative discrepancies between the WDXRF and EDXRF results are in the range of 2.0-18.0\%, and between the WDXRF and the NAA results are in the range of 2.0-20.0 \%. These values are less than $30 \%$, yielding the third category of the precision of the mineral raw material analysis.

Keywords: X-ray fluorescence spectrometry, XRF, uranium content, background standard method, coal ash, coal, phosphate ore, technological sample.

Cherkashina Tat iana Yur'evna - Ph.D in Geology and Mineralogy, Scientific researcher of the Analytical Center at the Institute of the Earth's Crust, SB RAS.

Field of research: X-ray fluorescence spectrometry of natural objects; geochemical studies of sediments, rocks, and minerals.

Published over 40 scientific articles.

Damdinsuren Bolortuya - Master of Science in Physics, Scientific researcher of the Nuclear Research Center, National University of Mongolia.

Field of research: X-ray fluorescence spectrometry of natural materials, nuclear analytical method.

Published over 30 scientific articles.

Revenko Anatolii Grigor'evich - Doctor of Technical sciences, Chief of the Analytical Center at the Institute of the Earth's Crust, SB RAS.

Field of research: physics of X-rays; X-ray fluorescence analysis of rocks, soils, sediments, ores, and cultural heritage materials.

Published over 320 scientific articles.

Purev Zuzaan - Doctor of Physics and Mathematics, Professor, Head of the division of Nuclear Analytical methods, the Nuclear Research Center, National University of Mongolia.

Field of research: the interaction of radiation with matter, $X$-ray fluorescence analysis.

Published over 250 scientific articles. 


\section{INTRODUCTION}

Mongolia has a vast wealth of mostly untapped mineral resources including coal, gold, phosphate, uranium and others. Therefore, it has about 150 billion ton of coals, 8 billion ton of phosphorites, and 74000 ton of uranium resources in addition to geological indications reported in the Red Book suggest that these uranium resources could be 1.47 million ton of $U$ [1].

The Mongolian government is attaching a great significance to mining uranium deposits, which would positively influence and improve national economy. It has developed the special Programme on uranium that should be implemented. The one guideline of this Programme is studying the possibilities of recovering uranium from phosphate and brown coal deposits and developing alternative extraction techniques [2].

In order to evaluate possibilities of recovering uranium, we should accurately determine the uranium content in geological samples such as brown coal, coal ash, and phosphate rock. There are several instrumental methods for the determination of the uranium and accompanying element contents in the geological samples such as gamma-activation analysis (GAA), neutron activation analysis (NAA), X-ray fluorescence (XRF) spectrometry, and others [3-14]. Each of these methods has benefits and drawbacks. XRF is a suitable method for geological problem solving, because (i) it does not require much preparation work, (ii) it has the multi-element capability, (iii) a wide dynamic range, (iv) high throughput and (v) low cost per a determination. Despite that, the problem of the uranium determination can be limited due to the high detection limit of this element. Several years ago, the uranium detection limit for an out-dated XRF spectrometer, which was located at the Nuclear Research Center (NRC) of the National University of Mongolia, was more than 50 ppm. In Mongolia, average uranium contents are 50200 ppm in the phosphate rock, 1-100 ppm in the coal, and $10-150 \mathrm{ppm}$ in the coal ash. The recent improvements in the XRF instrumentation have improved the sensitivity, the precision and the accuracy of the analysis. Nowadays, modern energy dispersive SPECTRO XEPOS XRF-spectrometer is installed at the NRC. Also, modern wavelength dispersion S8 TIGER XRF-spectrometer is located at the Analytical Center of the Institute of the Earth's Crust (IEC), SB RAS.

Purpose of the present work is to study the applicability of modern XRF equipments to the determination of the uranium content in Mongolian coal, coal ash, phosphate ore, and technological materials.

\section{EXPERIMENTAL}

\section{Instrumentation and measurement conditions}

The measurements were performed in a vacuum using a wavelength dispersive (WD) X-ray fluorescence spectrometer S8 TIGER (Bruker AXS GmbH, Germany). The WDXRF-spectrometer is equipped with a $4 \mathrm{~kW}$ power X-ray tube with a Rh anode and a Be window of
$75 \mu \mathrm{m}$ thickness. The incidence angle of the exciting beam and the take-off angle of the X-ray fluorescence are equal to 63 and 45 degrees, respectively. This device has a closed circuit of water cooling with a function of automatic adjustment of water flow and temperature. The measurement of the intensities of uranium and the influenced element analytical lines, and the background was conducted at the following conditions: $50 \mathrm{kV}$ operating voltage, $50 \mathrm{~mA}$ current, a LiF (200) analyzing crystal, a collimator with the angle aperture of $0.17^{\circ}$, a scintillation counter, a primary aluminum filter with 800 $\mu \mathrm{m}$ thickness. Detailed information about the S8 TIGER instrument can be found elsewhere [15].

Live counting time of each sample measurement was $1000 \mathrm{~s}$. The $L_{\alpha}$ line was used as the analytical line of $U$. Measurement time of the $U L_{\alpha}$ line was $300 \mathrm{~s}$. The $\mathrm{K}_{\alpha}$ lines were used as analytical lines of $\mathrm{Sr}$ and $\mathrm{Rb}$. Processing the X-ray spectra, numerical peak separation, and the correction of the matrix effects were performed using the spectrometer software SPECTRA ${ }^{\text {plus }}$ [16].

Moreover, all studied samples were transferred to the NRC of the National University of Mongolia and tested using modern energy dispersive (ED) SPECTRO XEPOS XRF-spectrometer. This device is equipped with an X-ray tube with a Pd anode and Peltier cooling, optimum excitation using eight polarization and secondary targets, a Si drift detector (SDD) with 155 eV spectral resolution for the $\mathrm{Mn} \mathrm{K}_{\alpha}$ line. The $\mathrm{UL}_{\alpha}$ line is excited by the radiation from $\mathrm{Al}_{2} \mathrm{O}_{3}$ polarization target and Mo secondary target of the EDXRF-spectrometer. So, we chose a technique in which these targets can be used. These measurements were conducted in an air. Live counting time was $300 \mathrm{~s}$ per sample. The EDXRF results were processed by the spectrometer software AXIL. The background standard method was successfully applied for the correction of the matrix effects.

NAA measurement data have been obtained by a cyclic accelerator microtron MT-22 at the NRC of the National University of Mongolia. The thermal neutrons were produced by the MT-22 device using Ta and $\mathrm{Pb}$ targets for $22 \mathrm{MeV}$ electron beam. For the absorption of the electrons gone through the Ta target, the Al $25 \mathrm{~mm}$ thick

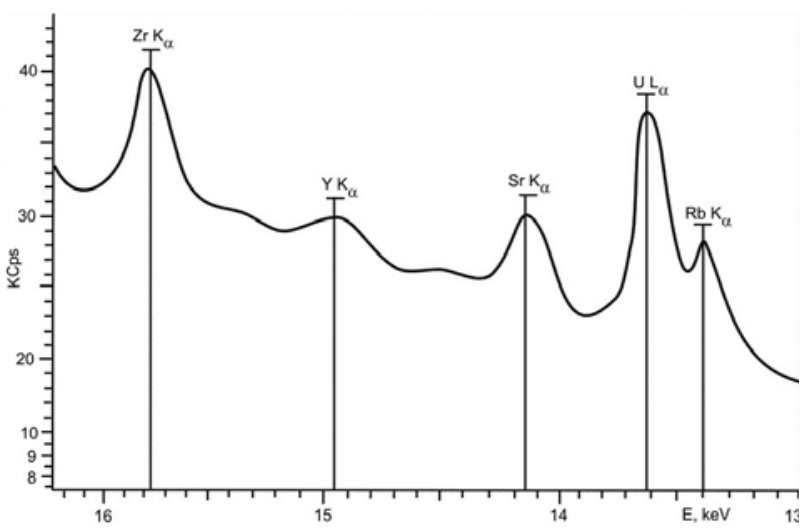

Fig. 1. Plot of the $X$-ray spectrum of the uranium ore RM URS-810 in $\mathrm{Zr} \mathrm{K}_{\alpha}-\mathrm{Rb} \mathrm{K}_{\alpha}$ energy range from 13 to $16 \mathrm{keV}$. This figure shows the effect of the $\mathrm{Rb} \mathrm{K}_{\alpha}$ and $\mathrm{Sr} \mathrm{K}_{\alpha}$ lines on the analytical signal intensity of the $U L_{\alpha}$ line, which should be taken into account 


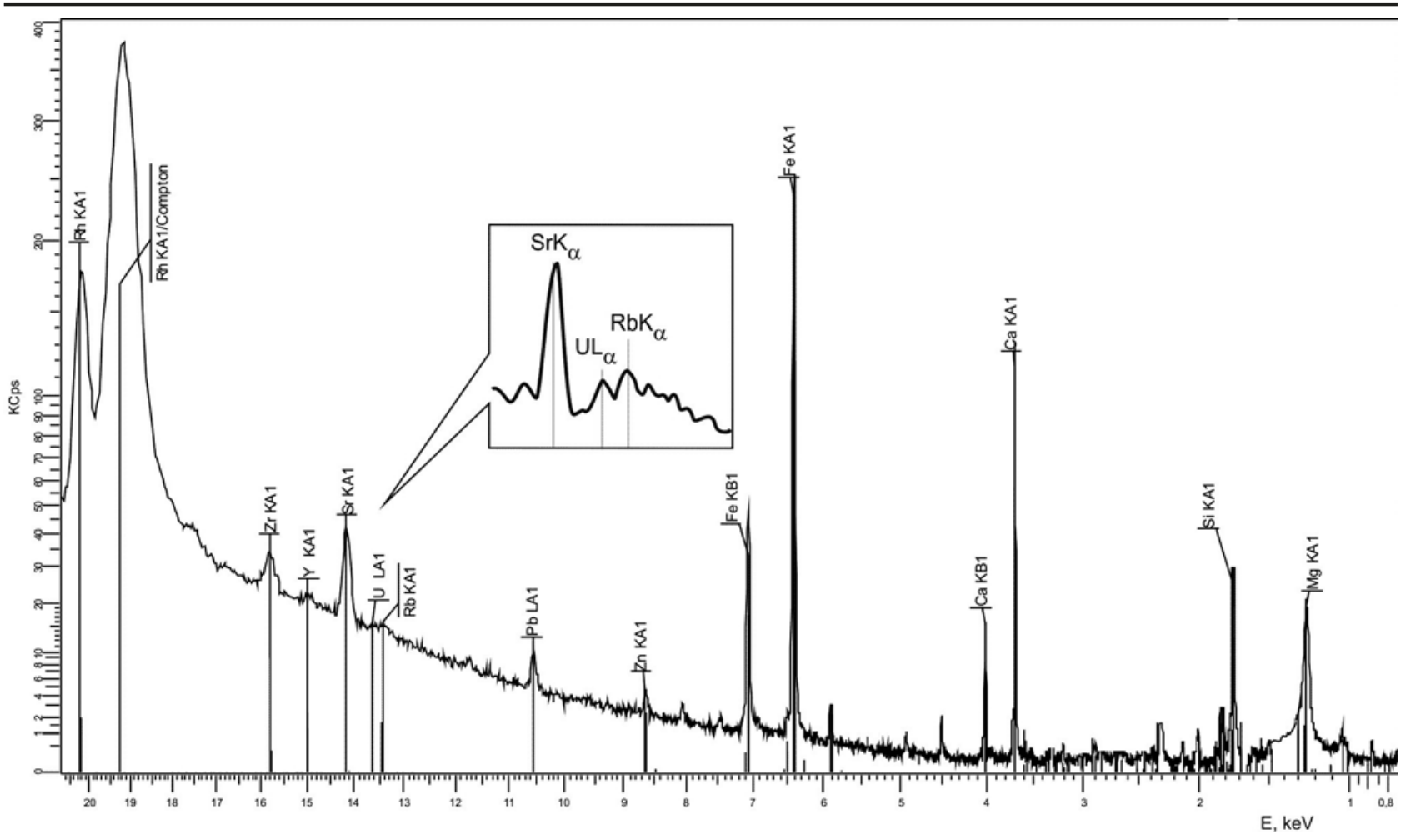

Fig. 2. X-ray spectrum of the phosphate ore sample 10-d2 in $\mathrm{Mg} \mathrm{K}_{\alpha}-\mathrm{Zr} \mathrm{K} \mathrm{a}_{\alpha}$ energy range from 1 to $20 \mathrm{keV}$

shield was used. The ${ }^{238} \mathrm{U}$ content has been determined registering a gamma-radiation from the ${ }^{239} \mathrm{~Np}$ isotope using line with energy of $228 \mathrm{keV}$. Each analyzed sample was irradiated by the neutrons during for two hours.

\section{WDXRF and EDXRF spectra}

WDXRF spectra have been obtained using the S8 TIGER spectrometer. Fig. 1 demonstrates the plot of the $\mathrm{X}$-ray spectrum of the uranium ore Reference Material (RM) URS-810 (Number of State Registry is 3161-85) in $\mathrm{Rb} \mathrm{K}_{\alpha}-\mathrm{Zr} \mathrm{K} \mathrm{K}_{\alpha}$ energy range in the neighbor of $\mathrm{UL}_{\alpha}$ analytical line. The uranium content in the RM is equal to $0.081 \%$ [16]. It can be seen, that the $U L_{\alpha}$ line angle position of $13.614 \mathrm{keV}$ is between $\mathrm{Rb} \mathrm{K}_{\alpha}$ of $13.396 \mathrm{keV}$ and $\mathrm{Sr} \mathrm{K}_{\alpha}$ of $14.165 \mathrm{keV}$ lines in the XRF spectrum. The $\mathrm{K}_{\alpha}$ line is higher by 3-4 times than the $\mathrm{L}_{\alpha}$ line intensity [5]. Thus, the effect of the $\mathrm{Rb} \mathrm{K}_{\alpha}$ and $\mathrm{Sr} \mathrm{K}_{\alpha}$ lines on the analytical signal intensity of the $U L_{\alpha}$ line must be taken into account.

Fig. 2 displays the X-ray spectrum of the phosphate ore sample 10d2 in $\mathrm{Mg} \mathrm{K}_{\alpha}-\mathrm{ZrK}_{\alpha}$ energy range, which selected from the Ongilog Lake, Mongolia. For the convenience, the plot of the spectrum in the range from 13 to $15 \mathrm{keV}$ is shown in the inset of Fig. 2. For the estimation of the uranium content the $\mathrm{Rb}$ and $\mathrm{Sr} \mathrm{K}_{\alpha}$ line overlaps on the $U L_{\alpha}$ line were taken into account by means of the SPECTRA ${ }^{\text {plus }}$ software. The Rh K $\mathrm{K}_{\alpha}$ Compton scattered radiation from the anode has been used as an analytical parameter (see Fig. 2). In from 1 to $18 \mathrm{keV}$ order to take into account the fluorescence peak overlaps, the $\alpha$-correction procedure was applied.

The EDXRF-spectrum has been obtained using the SPECTRO XEPOS instrument. Fig. 3 displays the $X$-ray spectrum of the Khuut coal ash sample in Si $\mathrm{K}_{\alpha}-\mathrm{Y} \mathrm{K}_{\alpha}$ energy range, which selected from coal mine located closely Dornod uranium deposit (Mongolia). For the convenience, the plot of the spectrum in the energy range from 13 to $15 \mathrm{keV}$ is separated in Fig. 3. For the estimation of the uranium content, overlaps of the $\mathrm{Rb} \mathrm{K}_{\alpha}$ and the $\mathrm{Sr} \mathrm{K}_{\alpha}$ lines on the $\mathrm{U} \mathrm{L}_{\alpha}$ line were taken into account using the AXIL software.

\section{Certified Reference Materials and research objects}

For the present study, different geological objects such as coal, coal ash, phosphate ore, and technological materials were chosen. These technological samples

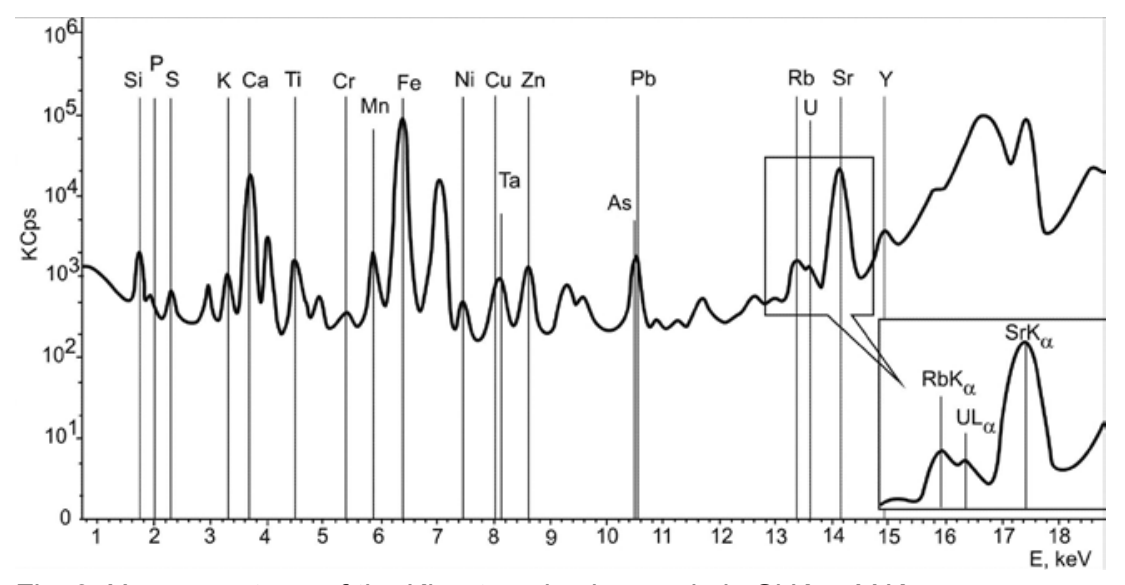

Fig. 3. X-ray spectrum of the Khuut coal ash sample in Si $\mathrm{K}_{\alpha}-\mathrm{Y} \mathrm{K}_{\alpha}$ energy range 
were chemically treated phosphorite samples. Binder (wax) was used for the preparation of these samples for XRF.

The Certified Reference Materials (CRMs) and the RMs with different uranium content have been used for the calibration of the XRF technique: coal ashes ZUK-1 and ZUA-1, Baikal mud BIL-1, granite SG-1, greisenized granite DVG, rhyolite RGM-1, uranium ore UKRS-72 (Number of State Registry is 3160-80), rare-earth ore TRHB [1719], and others. These CRMs and RMs were produced and certified by the Institute of Geochemistry (IG) of SB RAS, Irkutsk (ZUK-1, SG-1) [20], the United States Geological Survey (USGS) (RGM-1) [21], and the Central Geological Laboratory (CGL) of Mongolia (TRHB) [19].

\section{Sample preparation for XRF}

All the CRMs and the RMs are powders with a particle size smaller than $63 \mu \mathrm{m}$. The coal, the coal ash, the phosphate ore, and the technological samples were made to be homogeneous in granulometric and chemical composition with the particle size from 63 to $75 \mu \mathrm{m}$. The particle sizes of the CRMs and the geological sample powders were studied using the electron probe X-ray microanalyzer Superprobe JXA-8200 (JEOL, Japan) located at the Institute of Geochemistry, SB RAS (Irkutsk). The samples have been prepared in accordance with requirements given in [22]. Each sample powder weighing $5 \pm 0.0001 \mathrm{~g}$ and wax weighing $1 \pm 0.0001 \mathrm{~g}$ was taken using an analytic balance of AB-series (St. Petersburg, GOST 24104-2001). Then the sample powder and the wax have been mixed and thoroughly shaken for two minutes. Prepared samples were pressed using a HERZOG HTP-40 semiautomatic press with a pressure of $100 \mathrm{kN}$. The sieving procedure for these samples was not applied, because the fractionation procedure was not required. Then the prepared tablets were transferred to the S8 TIGER WDXRF-spectrometer and measured. During the measurement each analyzed sample is rotated at 30 r.p.m. (rotation per minute) to compensate the heterogeneity effects.

The sample preparation procedure for EDXRF analysis was the same as the procedure for WDXRF conducted at the Analytical Center of the IEC, SB RAS. The different rock and uranium ore CRMs were used for the calibration of the technique.

\section{RESULTS AND DISCUSSION}

\section{Statistical analysis}

Analytical figures of merit such as the total uncertainty, the accuracy of the uranium determination, and the detection limit (DL) were carefully studied, as exemplified by the rock, uranium ore CRMs and RMs.

To evaluate the total uncertainty in determining the uranium concentration in the analyzed samples, the single-factor variance analysis was carried out [23]. Each sample was measured three times a day. The total uncertainty (the variance $V_{\Sigma}$ ) was divided into two components [23]:

$$
V_{\Sigma}^{2}=V_{R}^{2}+V_{P}^{2},
$$

where $V_{R}$ is the variance, characterizing the reproducibility of the measurement of an analytical signal from one sample; $V_{P}$ is the variance, characterizing the stability of the sample preparation conditions from the same specimen.

The values of the components $V_{P}$ and $V_{R}$ were evaluated as well as in [23, 24]. Statistical processing of the analytical results was performed in accordance with the recommendations given at the confidence level $P=0.95$ [25]. The variance of the total uncertainty is $2 \%$ for $U$ in the analyzed samples, and one is $7 \%$ in the rock RMs. The values of the total uncertainty $V_{\Sigma}$ do not exceed the values of the permissible standard deviation $\sigma_{r}$ [22].

The detection limit of the uranium for the CRMs and RMs was estimated according to the $3 \sigma$ approach:

$$
D L=3 \times \sigma_{\text {blank }} \times\left(C / N_{n e t}\right),
$$

where $N_{\text {net }}$ is the net intensity (count rate), $C$ is the reference value of the concentration of the uranium in the CRM or the RM. The value of the $\sigma_{\text {blank }}$ characterizes the deviation from the background intensity of the blank sample. The $\sigma_{\text {blank }}$ value was estimated from the results of the background intensity measurement from 20 emitters obtained using silicon dioxide.

The DL values of the uranium were assessed for the S8 TIGER and SPECTRO XEPOS spectrometers, and equaled to 1 and 3 ppm, respectively.

The accuracy of the uranium determination in the studied samples was checked using the aforementioned CRMs. The obtained WDXRF and EDXRF results are summarized in Table 1. As it follows from Table 1, the values of the discrepancies between the WDXRF and EDXRF results and the reference values are less than $10 \%$, which is admissible for the analytical results of the geological samples [22]. These values were assessed from the relation $\left(C_{\mathrm{XRF}}-C_{\text {ref }}\right) / C_{\text {ref }}$.

Thus, the comparison of the WDXRF and EDXRF results with the reference values showed an agreement within the limits of the uncertainty for the uranium determination.

\section{Comparison of the WDXRF with EDXRF results and the neutron activation analysis}

Table 2 presents the comparison of the WDXRF results obtained by the S8 TIGER spectrometer with the EDXRF results derived by the SPECTRO XEPOS instrument and the neutron activation analysis (NAA). It can be found from Table 2 that the WDXRF results have satisfactorily agreed with the EDXRF results, and the NAA. The use of the background standard method provides the values of the relative discrepancies between the WDXRF and the EDXRF results in the range of $2.0-18.0 \%$, and between the WDXRF and the NAA results in the range of $2.0-20.0 \%$. These values are 
Table 1

The WDXRF and EDXRF results of the uranium determination in the analyzed Certified Reference Materials, ppm

\begin{tabular}{|c|c|c|c|}
\hline Methods & Certified Reference Materials & $C \pm \Delta$ & $C_{\text {ref }} \pm \Delta$ \\
\hline \multirow{2}{*}{ WDXRF } & STM-2 & $8.5 \pm 1.0$ & $7.6 \pm 0.8$ \\
\cline { 2 - 4 } & TRHB & $59.5 \pm 1.4$ & $57.0 \pm 1.0$ \\
\hline \multirow{3}{*}{ EDXRF } & BIL-1 & $15.4 \pm 2.0$ & $12.0 \pm 2.0$ \\
\cline { 2 - 4 } & DVG & $19.1 \pm 3.0$ & $17.0 \pm 2.7$ \\
\cline { 2 - 4 } & ZUA-1 & $13.2 \pm 2.0$ & $15.0 \pm 1.7$ \\
\cline { 2 - 4 } & ZUK-1 & $4.2 \pm 1.0$ & $3.3 \pm 0.7$ \\
\hline
\end{tabular}

Comment: ' $\Delta$ ' means that the confidence interval was calculated at the confidence level $P=0.95$ and the number of the measurements $n=6$. It can be found from the Table that the WDXRF and EDXRF results have satisfactorily agreed with the reference values within the limits of the uncertainty for the uranium determination.

less than $30 \%$, yielding the third category of the precision of the mineral raw material analysis [22].

\section{SUMMARY}

In the present work we have verified the possibilities and clarified the limitations of the XRF analysis of the Mongolian coal, coal ash, and phosphate ore to the geological studies focused on the uranium determination. The XRF technique of the uranium determination, which developed at the IEC of SB RAS using the S8 TIGER WDXRF-spectrometer, has been tested at the NRC (Mongolia) using the SPECTRO XEPOS EDXRF-spectrometer. Good analytical results were obtained for all samples studied with the limit of detection for U, which was equal to $1 \mathrm{ppm}$ for the S8 TIGER device, and 3 ppm for the SPECTRO XEPOS instrument.

The use of the background standard method provides the values of the discrepancies between the obtained WDXRF results and the reference values is less than $10 \%$. The comparison of the WDXRF with the
EDXRF results, and the NAA indicated that the values of the relative discrepancies between these results are within the interval from 2 to $20 \%$ depending on the level of the uranium content determined.

Finally, for our further investigations we can emphasize the WDXRF method. In spite of the good comparability of the WDXRF results with EDXRF and NAA, this one is more suitable method than the EDXRF for the determination of the uranium concentration is less than 3 ppm in the coal, coal ash, and phosphate rock. NAA is a time consuming and expensive method, and requires a nuclear reactor and long cooling times prior to the concentration measurements.

\section{ACKNOWLEDGEMENTS}

All studied samples were kindly supplied by the Nuclear Research Center of the National University of Mongolia. Main XRF results were obtained by means of material and technical base of the Baikal Analytical Center of SB RAS.

Table 2

The comparison of the WDXRF results obtained for the studied samples with the EDXRF and the NAA measurement data, ppm

\begin{tabular}{|c|c|c|c|c|}
\hline Sample & Type of the sample & WDXRF & EDXRF & NAA \\
\hline 9-d1 & Phosphate ore (the Ongilog Lake) & $15.1 \pm 1.4$ & $15.4 \pm 1.6$ & $14.8 \pm 0.3$ \\
\hline $10-d 2$ & Phosphate ore (the Ongilog Lake) & $27.0 \pm 2.4$ & $24.0 \pm 2.1$ & $23.3 \pm 0.6$ \\
\hline $11-d 3$ & Phosphate ore (the Ongilog Lake) & $12.6 \pm 1.1$ & $11.0 \pm 1.2$ & $11.3 \pm 0.3$ \\
\hline $12-\mathrm{d} 4$ & Phosphate ore (the Ongilog Lake) & $8.2 \pm 1.0$ & $9.6 \pm 1.0$ & $9.3 \pm 0.3$ \\
\hline Khuut coal & coal & $3.3 \pm 0.2$ & $3.2 \pm 0.3$ & $<0.1$ \\
\hline Khuut coal ash & coal ash & $35.0 \pm 3.0$ & $30.4 \pm 3.1$ & $35.7 \pm 0.4$ \\
\hline Baganuur ash & ash & $8.0 \pm 1.0$ & $8.2 \pm 1.2$ & $12.5 \pm 0.2$ \\
\hline Baganuur coal & coal & $3.0 \pm 0.1$ & $<3$ & $1.6 \pm 0.1$ \\
\hline № $1 \mathrm{~A}-1$ & Technological sample* $^{*}$ & $15.7 \pm 1.5$ & $15.9 \pm 1.7$ & $14.3 \pm 0.2$ \\
\hline № 2 A-1 & Technological sample & $13.5 \pm 1.3$ & $13.0 \pm 1.4$ & $16.9 \pm 0.2$ \\
\hline № $3 \mathrm{~A}-1$ & Technological sample & $13.5 \pm 1.3$ & $13.7 \pm 1.5$ & $12.0 \pm 0.1$ \\
\hline № 4 A-1 & Technological sample & $15.0 \pm 1.4$ & $15.0 \pm 1.6$ & $14.6 \pm 0.1$ \\
\hline № 5 A-2 & Technological sample & $20.3 \pm 1.8$ & $19.8 \pm 2.2$ & $19.8 \pm 0.2$ \\
\hline № $6 \mathrm{~A}-2$ & Technological sample & $15.5 \pm 1.5$ & $15.7 \pm 1.7$ & $15.2 \pm 0.2$ \\
\hline № $7 \mathrm{~A}-2$ & Technological sample & $24.4 \pm 2.0$ & $20.6 \pm 2.3$ & $22.6 \pm 0.2$ \\
\hline № 8 A-2 & Technological sample & $24.0 \pm 2.0$ & $22.1 \pm 2.6$ & $25.0 \pm 0.3$ \\
\hline
\end{tabular}

Comment: '<' means that the obtained result is less than the assessed detection limit;

'*' means that the samples were produced from phosphates by the chemical treatment. It can be found from Table 2 that the WDXRF results have satisfactorily agreed with the EDXRF results, and the NAA within the limits of the uncertainty for the uranium determination. 


\section{REFERENCES}

1. Uranium 2011: Resources, Production and Demand. A Joint Report by the OECD Nuclear Energy Agency and the International Atomic Energy Agency, ISBN 978-92-64-178038, 2012, pp. 17-22, 312-320.

2. $45^{\text {th }}$ ruling from Parliament of Mongolia which are the state policy on exploitation of radioactive minerals and nuclear energy, 2009, term-3.2.4.

3. Afonin V.P., Komiak N.I., Nikolaev V.P., Plotnikov R.I. Rentgenofluorestsentnyi analiz [X-ray fluorescence spectrometry]. Novosibirsk, Nauka Publ., 1991. 173 p. (in Russian). 4. Kuz'mina T.G., Bostrem B. [X-ray fluorescence technique of phosphate sediments]. Okeanologiia [Okeanology], 1994, vol. 34, no. 3, pp. 460-463 (in Russian).

5. Revenko A.G. Rentgenospektral'nyi fluorestsentnyi analiz prirodnykh materialov [X-Ray Spectral Fluorescence Analysis of Natural Materials]. Novosibirsk, Nauka Publ., 1994. 264 6. Hayumbu P., Haselberger N., Markowicz A. and Valkovic $\mathrm{V}$. Analysis of rock phosphates by X-ray fluorescence spectrometry. Appl. Radiat. Isot., 1995, vol. 46, no. 10, pp. 10031005. doi: 10.1016/0969-8043(95)00206-S.

7. Ewa I.O.B., Adetunji J., Elegba S.B. Determination of trace elements in Nigerian coal ash by instrumental neutron activation analysis. J. of Environmental Science and Health, Part A: Environm. Science and Health and Toxicology, 1996, vol. 31, no. 5, pp. 1089-1100. doi: 10.1080/10934529609376409. 8. Revenko A.G., Khudonogova E.V. [X-ray fluorescence determination of major and minor element contents in different types of rocks, soils, and sediments using S4 PIONEER spectrometer]. Ukrainskii khimicheskii zhurnal [Ukrainian chemical journal], 2005, vol. 71, no. 9-10, pp. 39-45. (in Russian). 9. Sabiha-Javied, Waheed S., Siddique N., Tufail M., Chaudhry M.M., Irfan N. Elemental analysis of phosphate rocks: For sustainable agriculture in Pakistan. J. of Radioanalyt. and Nuclear Chem., 2008, vol. 278, no. 1, pp. 17-24. doi: 10.1007/ s10967-007-7205-0.

10. Cherkashina T.Yu., Hudonogova E.V., Revenko A.G., Letnikova E.F. Application of the background standard method for the determination of $\mathrm{Rb}, \mathrm{Sr}, \mathrm{Y}, \mathrm{Zr}$, and $\mathrm{Nb}$ contents in phosphorites by $\mathrm{x}$-ray fluorescence. $X$-Ray Spectrometry, 2009, vol. 38, no 2, pp. 144-151. doi: 10.1002/xrs.1122.

11. Bolortuya D., Zuzaan P. [X-ray fluorescence technique for Determination of Uranium]. Trudy Konferentsii "Primenenie iadernoi energii v Mongolii" [Proc. of Conference on Nuclear Energy Application in Mongolia]. Ulaanbaatar, 2010, pp. 98-104. 12. Maslov O.D., Tserenpil Sh., Norov N., Gustova M.V., Filippov M.F., Belov A.G., Altangerel M., and Enhbat N. Uranium Recovery from Coal Ash Dumps of Mongolia. Solid Fuel
Chemistry, 2010, vol. 44, no. 6, pp. 433-438. doi: 10.3103/ S0361521910060133.

13. Cherkashina T.Yu. Geokhimiia fosforitov iuga Sibiri i severa Mongolii. Diss. kand. geol.-min. nauk [Phosphorite geochemistry of southern Siberia and northern Mongolia]. Irkutsk, 2010. 174 p. (in Russian).

14. Cherkashina T.Yu., Letnikova E.F. [Application of analytical methods for geochemical investigations of phosphorites of northern Mongolia]. Vestnik IrGTU [Vestnik of National Research Irkutsk State University], 2012, no. 6, pp. 59-65 (in Russian).

15. S8 TIGER XRF Spectrometer. Service Manual. Berlin, Bruker AXS GmbH Publ., 2007. 450 p.

16. SPECTRA plus. Software Package for X-ray Spectrometers. Version 2.2.3.1. Karlsruhe, Bruker AXS GmbH Publ., 2010. 495 p.

17. Arnautov N.V. Standartnye obraztsy khimicheskogo sostava prirodnykh mineral'nykh veshchestv [Certified Reference Materials of chemical composition of natural mineral substances]. Novosibirsk, Institute of Geology and Geophysics, SB AN USSR Publ., 1990. 220 p. (in Russian).

18. Govindaraju K. Compilation of working values and sample description for 383 geostandards. Geostand. Newslett. J. Geostand: Geoanalysis: Spec. Iss., 1994, vol. 18, pp. 1-158. 19. Central Geological Laboratory: Catalog of CRMs. Available at: http://www.cengeolab.com/ct/ci/974/656/Catalog of CRMs (accessed 15 March 2014).

20. Institute of Geochemistry, SB RAS: Catalog of RMs. Available at: http://igc.irk.ru/Innovation/Standarts-obr/Catalog-2013.pdf (accessed 15 March 2014).

21. United States Geological Survey: Catalog of RMs. Available at: http://crustal.usgs.gov/geochemical_reference_standards/powdered_RM.html (accessed 13 March 2014).

22. OST 41-08-205-04. Metodiki kolichestvennogo khimicheskogo analiza. Razrabotka, attestatsiia, utverzhdenie. [Industry Standard 41-08-205-04. Methods of quantitative chemical analysis. Development, certification, confirmation]. Moscow, Standard Publ., 2005. 96 p. (in Russian).

23. Smagunova A.N., Karpukova O.M. Metody matematicheskoi statistiki $v$ analiticheskoi khimii [Methods of mathematical statistics in analytical chemistry]. Irkutsk, State University Publ., 2008. 339 p. (in Russian).

24. Cherkashina T.Yu., Panteeva S.V., Finkelshtein A.L. and Makagon V.M. Determination of $\mathrm{Rb}, \mathrm{Sr}, \mathrm{Cs}, \mathrm{Ba}$, and $\mathrm{Pb}$ in K-feldspars in small sample amounts by total reflection X-ray fluorescence. X-Ray Spectrometry, 2013, vol. 42, no. 4, pp. 207-212. doi: 10.1002/xrs.2469.

25. Guide to Quality in Analytical Chemistry. An Aid to Accreditation. Citac and Eurachem Publ., 2002, 57 p.

\title{
РАЗРАБОТКА МЕТОДИКИ РЕНТГЕНОФЛУОРЕСЦЕНТНОГО ОПРЕДЕЛЕНИЯ УРАНА В МОНГОЛЬСКОМ УГЛЕ, ЗОЛЕ УГЛЯ И ФОСФАТНОЙ РУДЕ
}

\author{
Т.Ю. Черкашина', Д. Болортуяа², А.Г. Ревенко', П. Зузаан² \\ 1 Институт земной коры СО РАН, \\ Российская Федерация, 664033, Иркутск, ул. Лермонтова, 128 \\ tcherk@crust.irk.ru \\ ${ }^{2}$ Центр ядерных исследований, Национальный Университет Монголии, \\ Монголия, 210646, Улан-Батор, ул. Университетская, 1
}


Представлены результаты определения урана в Монгольском буром угле, золе угля, фосфатной руде и технологических образцах методом рентгенофлуоресцентного анализа (РФА). Технологические образцы получены из фосфатов при помощи химической обработки. Порошки геологических и стандартных образцов (СО) прессовали в виде таблеток. Для выбранных условий подготовки проб оценены метрологические характеристики методики на примере СО горных пород и урановой руды. Суммарная погрешность определения урана составила $2 \%$ для анализируемых образцов и 7 \% для СО горных пород. Оцененные значения предела обнаружения урана для СО находятся в интервале от 1 до 3 ppm. Способ стандарта фона использован для коррекции матричных эфффектов. Диапазон определяемых содержаний урана в изученных образцах составил 3.0-35.0 ppm.

Проведено сравнение результатов волно-дисперсионного (ВД) РФА с результатами энерго-дисперсионного (ЭД) РФА и нейтронно-активационного (НАA) анализа. Продемонстрировано, что результаты ВДРФА удовлетворительно согласуются с результатами ЭДРФА и НАА в пределах суммарной погрешности анализа. Показано, что относительные расхождения между результатами ВДРФА и ЭДРФА находятся в диапазоне 2.0-20.0 \%. Эти значения не превышают 30 \%, что соответствует III категории точности анализа минерального сырья.

\section{ЛИТЕРАТУРА}

1. Uranium 2011: Resources, Production and Demand. A Joint Report by the OECD Nuclear Energy Agency and the International Atomic Energy Agency, ISBN 978-92-64-178038, 2012, pp. 17-22, 312-320.

2. $45^{\text {th }}$ ruling from Parliament of Mongolia which are the state policy on exploitation of radioactive minerals and nuclear energy, 2009, term-3.2.4.

3. Афронин В.П., Комяк Н.И., Николаев В.П., Плотников Р.И. Рентгенофрлуоресцентный анализ. Новосибирск: Наука, 1991. 173 с.

4. Кузьмина Т.Г., Бострём Б. Методика рентгеноспектрального флуоресцентного анализа фосфорсодержащих осадков // Океанология. 1994. Т. 34, № 3. С. 460-463. 5. Ревенко А.Г. Рентгеноспектральный флуоресцентный анализ природных материалов. Новосибирск: Наука, 1994. 264 с.

6. Analysis of rock phosphates by X-ray fluorescence spectrometry / P. Hayumbu [et al.] // Appl. Radiat. Isot. 1995. V. 46, № 10. P. 1003-1005.

7. Ewa I.O.B., Adetunji J., Elegba S.B. Determination of trace elements in Nigerian coal ash by instrumental neutron activation analysis // J. of Environmental Science and Health, Part A: Environm. Science and Health and Toxicology. 1996. V. 31, № 5. Р. 1089-1100.

8. Ревенко А.Г., Худоногова Е.В. Рентгенофлуоресцентное определение содержаний неосновных и следовых элементов в различных типах горных пород, почв и отложений с использованием спектрометра S4 Pioneer // Укр. Хим. Журн. 2005. Т. 71, № 9-10. С. 39-45.

9. Elemental analysis of phosphate rocks: For sustainable agriculture in Pakistan / Sabiha-Javied [et al.] // J. of Radioanalyt. and Nuclear Chem. 2008. V. 278, №. 1. P. 17-24.

10. Application of the background standard method for the determination of $\mathrm{Rb}, \mathrm{Sr}, \mathrm{Y}, \mathrm{Zr}$, and $\mathrm{Nb}$ contents in phosphorites by x-ray fluorescence / T.Yu. Cherkashina [et al.] // X-Ray Spectrometry. 2009. V. 38, № 2. P. 144-151.

11. Bolortuya D., Zuzaan P. X-ray fluorescence technique for Determination of Uranium // Proceedings of Conference on Nuclear Energy Application in Mongolia, Ulaanbaatar, 2010. P. 98-104.

12. Maslov O.D., Tserenpil Sh., Norov N., Gustova M.V., Filippov M.F., Belov A.G., Altangerel M., and Enhbat N. Uranium
Recovery from Coal Ash Dumps of Mongolia // Solid Fuel Chemistry. 2010. V. 44, № 6. P. 433-438.

13. Черкашина Т.Ю. Геохимия фосфоритов юга Сибири и севера Монголии: дис. канд. геол.-мин. наук: 25.00.09. Иркутск, 2010. 174 с.

14. Черкашина Т.Ю., Летникова Е.Ф. Применение аналитических методов для геохимических исследований фросфоритов севера Монголии // Вестник ИрГТУ. 2012. № 6. C. 59-65.

15. S8 TIGER XRF Spectrometer. Service Manual. Berlin: Bruker AXS GmbH, 2007. 450 p.

16. SPECTRA ${ }^{\text {plus }}$. Software Package for $X$-ray Spectrometers. Version 2.2.3.1. Karlsruhe: Bruker AXS GmbH, 2010. 495 p. 17. Арнаутов Н.В. Стандартные образцы химического состава природных минеральных веществ. Новосибирск: Институт геологии и геофизики СО АН СССР, 1990. 220 с. 18. Govindaraju K. Compilation of working values and sample description for 383 geostandards. Geostand. Newslett. J. Geostand: Geoanalysis: Spec. Iss. 1994. V. 18. P. 1-158.

19. Central Geological Laboratory: Catalog of CRMs. [Электронный ресурс]: http://www.cengeolab.com/ct/ci/974/656/ Catalog of CRMs (дата обращения 15.03.2014).

20. Институт геохимии им. А.П. Виноградова СО РАН: Каталог стандартных образцов. [Электронный ресурс]: http://igc.irk.ru/Innovation/Standarts-obr/Catalog-2013.pdf (дата обращения 15.03.2014).

21. United States Geological Survey: Catalog of RMs. [Электронный ресурc]: http://crustal.usgs.gov/geochemical_ reference_standards/powdered_RM.html (дата обращения 15.03.2014).

22. ОСТ 41-08-205-04. Методики количественного химического анализа. Разработка, аттестация, утверждение. М., 2005. 96 с.

23. Смагунова А.Н., Карпукова О.М. Методы математической статистики в аналитической химии: учеб. пособие. Иркутск: ИГУ, 2008. 339 с.

24. Cherkashina T.Yu., Panteeva S.V., Finkelshtein A.L. and Makagon V.M. Determination of Rb, Sr, Cs, Ba, and $\mathrm{Pb}$ in K-feldspars in small sample amounts by total reflection X-ray fluorescence // X-Ray Spectrometry. 2013. V. 42, № 4. P. $207-212$.

25. Guide to Quality in Analytical Chemistry. An Aid to Accreditation. Citac and Eurachem, 2002. 57 p. 